\title{
Symptomatic congenital syphilis: still a reality
}

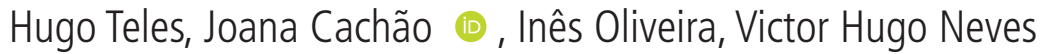

Department of Pediatrics, Centro Hospitalar de Setubal EPE, Setúbal, Portugal

\section{Correspondence to \\ Dr Joana Cachão:} joanacbc@hotmail.com

Accepted 1 May 2020

\section{DESCRIPTION}

We describe the case of a newborn, first daughter of young parents, both unemployed, with no history of bisexual behaviour, sex work, drug use, social marginalisation, prison, domestic violence or any other known social risk factor. The pregnancy was unplanned and poorly monitored. The ultrasounds, performed at 14th and 22th weeks of gestation, were normal. Both the Venereal Disease Research Laboratory (VDRL) test (1/8) and the Treponema pallidum haemagglutination test were reactive $(1 / 1280)$ in the third trimester, HIV was negative. However, she missed her appointment and consequently was not medicated. At 34 weeks of gestation, due to placental abruption, emergency caesarean delivery was performed. The newborn needed reanimation with invasive mechanical ventilation and was transferred to an intensive neonatal care unit. At birth, it was evident a widely disseminated and bullous rash (pemphigus syphiliticus), hepatomegaly, anaemia (haemoglobin $111 \mathrm{~g} / \mathrm{L}$ ), hypoglycaemia $(14 \mathrm{~g} / \mathrm{dL})$ and jaundice $(10.4 \mathrm{mg} /$ $\mathrm{dL})$. VDRL titre was more than fourfold the corresponding maternal titre (1/128). Cerebrospinal fluid VDRL was non-reactive and cerebral ultrasound, hearing test and eye examination were normal. A chest radiograph showed bilateral perihilar infiltrate, suggestive of pneumonitis and the long-bone radiographs periostitis and osteochondritis of the lower limbs (figure 1). The diagnosis of congenital syphilis was made and she was treated with intravenous aqueous penicillin G $(50000 \mathrm{U} / \mathrm{kg}$ per dose every 12 hours during the first 7 days and every 8 hours for a total of 10 days). Both parents were

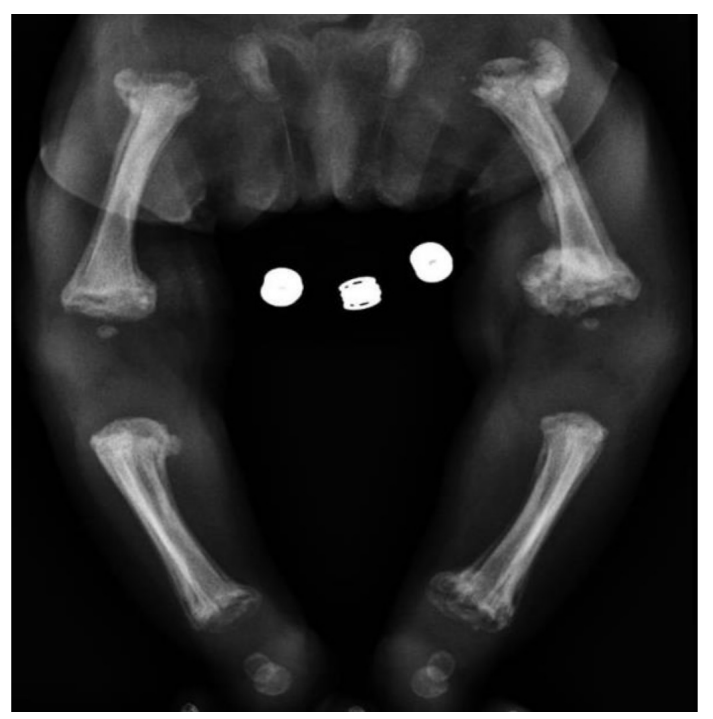

Figure 1 Skeletal radiography: diaphyseal periostitis and osteochondritis in long bones (tibia and femur).

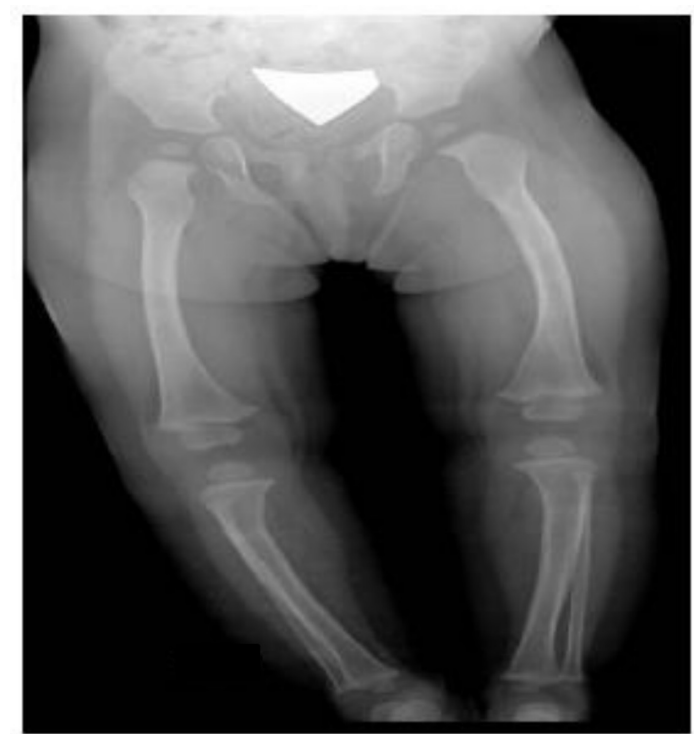

Figure 2 Skeletal radiography (12 months): no signs of periostitis or osteochondritis of the long bones.

treated with intramuscular benzathine penicillin $G$ and cases duly notified.

At 4 months VDRL was negative and at 12 months she was asymptomatic, without neurodevelopmental problems or evident osseous lesions (figure 2).

Although it is preventable and traceable, with an easy and cheap treatment, syphilis has a high prevalence worldwide (about 19 million people infected), and its incidence has been rising in recent years, which is likely to be associated with an increase in underprivileged and high-risk populations. ${ }^{1}$ In Portugal, 451 cases of syphilis were reported between 2013 and 2017, of which 23 were of congenital syphilis. ${ }^{2}$

We are reporting a case of symptomatic congenital syphilis, with multisystemic involvement,

\section{Learning points}

Congenital syphilis is still a major public health issue, including in developed countries.

- Repeated serology during pregnancy is recommended, especially if risk factors are present.

- The diagnosis of congenital syphilis should be considered in any infant with suspicious clinical findings, despite maternal serological status, in order to establish early diagnosis and institute appropriate treatment, avoiding the high morbidity and mortality associated with the disease. 
manifested by prematurity, anaemia, jaundice, hypoglycaemic and cutaneous, bone and pulmonary lesions. In this case, institution of appropriate therapy was delayed because of incomplete follow-up, not only due to several missed appointments by the mother, as well as lack of communication between health services and the patient. We spot the fact that it is fundamental to comply with the pregnancy follow-up, once all the appointments are free of charge and of easy access. We also point the need to design collaboration protocols between laboratories, general practitioner and patient, especially in high-risk groups for sexually transmitted diseases. The diagnosis of the infection in the mother and its adequate treatment is essential in order to prevent its high mortality and morbidity in the newborn. ${ }^{34}$

Contributors HT: conception of the work, analysis and interpretation of data, drafting the work, final approval of the version published. JC: revising the work critically for important intellectual content, final approval of the version published.

IO: revising the work critically for important intellectual content, final approval of the version published. VHN: revising the work critically for important intellectual content, final approval of the version published.

Funding The authors have not declared a specific grant for this research from any funding agency in the public, commercial or not-for-profit sectors.

Competing interests None declared.

Patient consent for publication Parental/guardian consent obtained.

Provenance and peer review Not commissioned; externally peer reviewed.

\section{ORCID iD}

Joana Cachão http://orcid.org/0000-0003-4337-9658

\section{REFERENCES}

1 Chlamydia, gonorrhoea, trichomoniasis and syphilis: global prevalence and incidence estimates, 2016, 2019. Available: https://www.who.int/bulletin/volumes/97/8/18228486.pdf [Accessed 20 Nov 2019].

2 European Centre for Disease Prevention and Control. Syphilis. In: Annual epidemiological report for 2017. Stockholm: ECDC, 2019.

3 Lago EG, Vaccari A, Fiori RM, et al. Clinical features and follow-up of congenital syphilis. Sex Transm Dis 2013;40:85-94.

4 Stafford IA, Sánchez PJ, Stoll BJ. Ending congenital syphilis. JAMA 2019;322:2073.

Copyright 2020 BMJ Publishing Group. All rights reserved. For permission to reuse any of this content visit https://www.bmj.com/company/products-services/rights-and-licensing/permissions/

BMJ Case Report Fellows may re-use this article for personal use and teaching without any further permission.

Become a Fellow of BMJ Case Reports today and you can:

- Submit as many cases as you like

- Enjoy fast sympathetic peer review and rapid publication of accepted articles

- Access all the published articles

- Re-use any of the published material for personal use and teaching without further permission

Customer Service

If you have any further queries about your subscription, please contact our customer services team on +44 (0) 2071111105 or via email at support@bmj.com.

Visit casereports.bmj.com for more articles like this and to become a Fellow 